\title{
Analysis on Occupants' Satisfaction for Safety Performance Assessment in Low Cost Housing
}

\author{
Husrul Nizam Husin ${ }^{1}$, Abdul Hadi Nawawi ${ }^{2}$, Faridah Ismail ${ }^{3}$, Natasha Khalil ${ }^{4}$ \\ ${ }^{1,2,3}$ Faculty of Architecture, Planning and Surveying, Universiti Teknologi MARA Perak, Seri \\ Iskandar, Malaysia \\ ${ }^{1,4}$ Faculty of Architecture, Planning and Surveying, Universiti Teknologi MARA, Shah Alam, \\ Selangor, Malaysia
}

\begin{abstract}
The delivery performance of the low cost housing is questioned since the occupants are prone towards safety hazards in the housing complex, such as structural instability and falling building fragments. Without defining the occupants' requirements for the development of low cost housing, the prevailing safety factors are hard to be determined. This paper explores the rationale of safety performance assessment in the low cost housing by considering the occupants' participation to achieve a better safety provision during occupancy period. Questionnaire survey was distributed to 380 occupants of the low cost housing in Kuala Lumpur and Selangor, Malaysia. The result shows that $80.8 \%$ of the respondents had expressed their dissatisfaction with the safety performance of the lift. By referring to the mode of ranking level, the most significant aspect rated by the respondents is Building Safety Features, with $51.6 \%$ respondents. The attained aspects can be fundamental parameters which can be considered in the future development of low cost housing.
\end{abstract}

\section{Introduction}

The move to build more low cost homes as announced in $9^{\text {th }}$ Malaysia Plan is inevitable a welcome sign in view of the spiralling property prices in the country. While the previous efforts in housing have been directed towards meeting the quantitative shortage of dwellings, safety aspects of housing have gained importance in recent years. Many cases have shown that most buildings fail to meet their objectives right from the moment they were declared complete. Therefore, to enhance the performance and quality of a building, safety requirements must be strategized during the preliminary design planning of any building development. Ramly et al. [1] revealed that safety has become the major objective in maintaining a building sustainability. Thus, safety has become one of the factors that contribute to poor performance in a building.

Users are currently getting more conscious of safety issues in housing environments. Kowaltowski [2] stated that local housing developments, especially built for low-income level families are slow in adopting recommended practices and perpetuate a standard design model often not adapted to specific geographic and social situations. It was found that over the years, the government has tried a number of different approaches in an effort to respond to changing conditions and the need for suitable in property, especially in LCH issues. Sadly, the process of designing, construction, location and allocation of low cost housing are totally controlled by the local 
government officials and the private developers without any participation from the building occupants. Hence, a structured safety performance assessment is needed to provide a link between design criteria and user desires towards a better safe living.

\section{Safety Performance Assessment}

Much study relates the term of "performance" as of a building is fulfillment, presentation, exhibition, achievement of building functions. Safety performance can be defined as establishment of a building related to the measured indicators to ensure that a building is safe. Any consequences derived from a poor safety management, for example accidents and incidents, are described as safety performance [3]. The benchmark of "performance" must be clearly identified in conducting safety performance assessment. Established safety performance schemes are necessary support on why technical performances and quality assessment are included as the main component of a safe building for low cost housing in Malaysia.

The schemes includes the Building Quality Assessment (BQA) in Australia and New Zealand, the Building Safety and Condition Index (BSCI), the Building Environmental Assessment Method (HKBEAM), the Comprehensive Environmental Performance Assessment Scheme for Buildings (CEPAS), the Standard of House Performance Appraisal (SHPA) in Mainland China and the Housing Performance Evaluation Model (HPEM) in South Korea. Several of the schemes, i.e. SHPA in China, and HPEM in Korea shows a comprehensive approach to measure the housing performance $[4,5]$.

These schemes developed a weightage rating scale to indicate the level of safety performance in residential buildings. Hence, assessment of safety performance in Malaysia's low cost housing is therefore needed to promote the significant of performance of housing. Such assessment is therefore must incorporate major concerns the safety and health performance of occupants in residential building [5].

\subsection{Reviewing on the aspects of performance in low cost housing}

Low cost housing implies a lower standard of housing and in trying to provide affordable housing the standard of houses is always being compromised. Affordable homes owned and medium cost housing indispensable quality in the city. Junaidi et al. [6] stated that the quality of housing has affected the safe, clean and attractive built environment in community. Therefore, each city must ensure that every family has a safe place to stay comfortable and healthy. Although there are differences between quality and safety, as has been pointed out, they are neither mutually exclusive nor contradictory. Whether a building is rated under good or poor performance, the rating is highly related to the failure of safety in the building. Hence, as stated by Yau [4], performance in safety has become one of the attributes of building quality. Previous research revealed that studies on building quality generally focused on commercial properties whether if they were in terms of energy efficiency, health, building intelligence, or sustainability. Structure failures, falling objects, fire hazards, services failures and special hazards are the main key elements in a safe building [4]. These identified safety hazards are useful in defining a safe building. The significance of having a highly performance of a building is because it leads to the building sustainability. [2] indicates quality relates to the safety, that the user attitudes depend on the psychological well-being, feelings of security and safety and the perception of space as territory. Based on the review of safety issues in LCH, generally, safety can be categorized under two elements; structural elements and services item $[2,4,7]$

\subsection{Benchmarking the Performance Input by Occupant's Perception}

Occupants or residents are the end-users of a housing unit and their satisfaction entailing the overall aspects of a building. Learning from how buildings perform is the fastest and surest way to improve 
the economic and environmental performance of buildings; and to achieve greater user satisfaction [8]. According to Mohit et al. [9], there is a need to determine satisfaction with households' housing conditions that able to "indicate the absence of any complaints and a high degree of congruence between actual and desired situations". Hence, the definition of satisfaction level must be clarified to understand the mutual interaction of satisfaction of the occupants with the safety performance of their housing unit. Therefore, feedback from the occupants is important in determining the customer's attributes to be incorporated into the design of a new product or upgrading the features of an existing product. As concluded by Khalil [10], the approach of POE has a great potential in analyzing building performance as it uses a strategic approach to achieve the best quality in building services, whereby the assessment integrates the building occupants' behavior, perception and opinion as the building users. By empowering end-users as the benchmarks of evaluation, it will show how the end product (the building design and its management) meets the needs of its clients.

\section{Methodology}

The research study utilizes a mixed-method design; using both qualitative and quantitative approach. Some authors debated that when a research facilitates validation of data through cross verification from more than two sources, it is called as triangulation. The main survey for this research used Occupants' Satisfaction Survey (OSS) as the instrument in quantitative approach. The survey is intended to determine occupants' satisfaction level in several safety performance attributes that were compiled from various literatures. The performance attributes of safety in the low cost housing were preliminarily validated from the findings of semi-structured interviews to building and safety experts. The survey was conducted by distributing the questionnaires to the identified occupants. Questionnaire set initially records the name of building and is divided into three separate sections, namely, i) Section A: Demographic Information, ii) Section B: Occupants' Satisfaction Level and iii) Section C: Perception on the Necessity of Housing. However, the discussion in this paper only provides the results on Section B and C. Utilizing the five points Likert-scale, the respondents were requested to respond to each statement in the questionnaire in term of five degrees of satisfaction.

\section{Analysis and Finding}

The survey was distributed to 380 respondents that represent as the occupants of twenty-four (24) low cost housing area namely Projek Perumahan Rakyat (PPR) (see Table 1), that is located in the Federal Territory of Kuala Lumpur. PPR is a Government program to accommodate and meet the needs of all slum dwellings for low-income earners. National Housing Department (JPN), the Ministry of Housing and Local government is the implementing agency for PPR projects across the country. Kuala Lumpur is the capital and the largest city of Malaysia and it covers a land area of $244 \mathrm{sq} \mathrm{km} \mathrm{(94}$ sq mile), occupied 1.63 million people according to census projections in 2010 [6]. Kuala Lumpur belongs in a large metropolitan area, which also includes most of the state, namely Klang Valley, as the mass of the occupied city with 7.2 million people, and the metropolitan area's fastest developing countries in terms of population and economy.

Table 1: Detail information of PPR housing projects

\begin{tabular}{|c|l|c|c|c|}
\hline No. & \multicolumn{1}{|c|}{ Housing Projects } & $\begin{array}{c}\text { Total No. Of } \\
\text { Units }\end{array}$ & $\begin{array}{c}\text { Total No. Of } \\
\text { Blocks }\end{array}$ & $\begin{array}{c}\text { Date Of Handing } \\
\text { Over }\end{array}$ \\
\hline 1 & PPR Taman Intan Baiduri & 1,834 & 6 & 15.04 .2004 \\
\hline 2 & PPR Kg. Muhibbah, Jalan Puchong & 2,844 & 9 & 22.12 .2006 \\
\hline 3 & PPR Kl Linear City 1 (PPR Seri Anggerik) & 316 & 1 & 15.01 .2003 \\
\hline 4 & PPR Ampang Hilir (PPR Hiliran Ampang) & 948 & 3 & 16.12 .2004 \\
\hline 5 & PPR Taman Wahyu I (PPR Beringin) & 1,896 & 6 & 31.03 .2003 \\
\hline 6 & PPR Pekan Batu & 632 & 2 & 03.12 .2002 \\
\hline
\end{tabular}




\begin{tabular}{|c|l|c|c|c|}
\hline 7 & PPR Malaysia Permai (PPR Raya Permai) & 1,264 & 4 & 2.06 .2006 \\
\hline 8 & PPR K1 Linear City Ii Fasa 1 (PPR Pantai Ria) & 1,264 & 4 & 08.08 .2007 \\
\hline 9 & PPR Sg. Besi (PPR Desa Petaling) & 632 & 2 & 19.08 .2002 \\
\hline 10 & PPR Kg. Baru Air Panas & 2,528 & 8 & 1.05 .2007 \\
\hline 11 & PPR Taman Wahyu II (PPR Wahyu) & 948 & 3 & 07.04 .2002 \\
\hline 12 & PPR Kg Batu Muda (Spnb) & 2,132 & 7 & 31.12 .2006 \\
\hline 13 & PPR Lembah Pantai, Kerinchi & 1,896 & 6 & 31.3 .2007 \\
\hline 14 & PPR Pudu Hulu & 948 & 3 & 15.01 .2003 \\
\hline 15 & PPR K1 Linear City II Fasa & 632 & 2 & 08.08 .2007 \\
\hline 16 & PPR Salak Selatan & 632 & 2 & 24.06 .2004 \\
\hline 17 & PPR Seri Malaysia & 632 & 2 & 03.1 .2007 \\
\hline 18 & PPR Sg. Bonus Air Jernih & 632 & 2 & 14.02 .2005 \\
\hline 19 & PPR Seri Semarak & 1,580 & 5 & 12.06 .2005 \\
\hline 20 & PPR Jln. Lapangan Terbang Lama Fasa 1 & 660 & 5 & 29.04 .2004 \\
\hline 21 & PPR Jln Cochrane & 1,620 & 5 & 25.04 .2005 \\
\hline 22 & PPR Kg. Limau Pantai Dalam & 632 & 2 & 15.1 .2005 \\
\hline 23 & PPR Pekan Kepong & 948 & 3 & 08.04 .2010 \\
\hline 24 & PPR Jln. Lapangan Terbang Lama Fasa 2 & 920 & 7 & 12.07 .2010 \\
\hline \multicolumn{2}{|l|}{ TOTAL } & 28,970 & 99 & \\
\hline
\end{tabular}

\subsection{Occupants' Satisfaction Levels}

The survey provides the respondents to rate their satisfaction level based on five numerical likert-scale (" 1 to " 5 ", very dissatisfied to very satisfied) for 12 safety performance attributes that categorised for four (4) safety elements. The analysis was shown in Table 2, in accordance to the category of safety; i.e. performance category and quality category.

Table 2: Occupants' Satisfaction Level on Safety Attributes

\begin{tabular}{|c|c|c|c|c|c|c|}
\hline \multirow{2}{*}{ Performance Category } & \multicolumn{3}{|c|}{ Percentage Result For Occupants' Satisfaction Level } \\
\hline \multirow{2}{*}{ Elements } & Attributes & $\begin{array}{c}\text { Very } \\
\text { Dissatisfied }\end{array}$ & Dissatisfied & $\begin{array}{c}\text { Moderately } \\
\text { Satisfied }\end{array}$ & Satisfied & $\begin{array}{c}\text { Very } \\
\text { Satisfied }\end{array}$ \\
\hline \multirow{3}{*}{ Structural } & Column / beam & $0.5 \%$ & $6.1 \%$ & $29.5 \%$ & $60.5 \%$ & $2.6 \%$ \\
\cline { 2 - 7 } & Roof & $0.3 \%$ & $7.1 \%$ & $30.8 \%$ & $59.2 \%$ & $1.6 \%$ \\
\cline { 2 - 7 } & Slabs & $0.5 \%$ & $8.7 \%$ & $38.7 \%$ & $48.2 \%$ & $2.4 \%$ \\
\hline \multirow{3}{*}{ Services } & Electrical Services & $0.5 \%$ & $33.2 \%$ & $25.5 \%$ & $37.9 \%$ & $2.1 \%$ \\
\cline { 2 - 7 } & Plumbing System & $1.6 \%$ & $12.4 \%$ & $28.9 \%$ & $54.7 \%$ & $1.6 \%$ \\
\cline { 2 - 7 } & Fire System & $0.5 \%$ & $20.5 \%$ & $47.4 \%$ & $29.7 \%$ & $1.1 \%$ \\
\hline \multirow{3}{*}{ Maintenance } & Playground & $0.5 \%$ & $7.1 \%$ & $59.5 \%$ & $30.8 \%$ & $0.8 \%$ \\
\cline { 2 - 7 } & Vehicle Parking & $1.1 \%$ & $20.3 \%$ & $53.7 \%$ & $23.2 \%$ & $0.0 \%$ \\
\cline { 2 - 7 } & Traffic safety & $0.8 \%$ & $13.2 \%$ & $58.4 \%$ & $24.5 \%$ & $0.5 \%$ \\
\cline { 2 - 7 } & Drainage cleanliness & $4.7 \%$ & $23.9 \%$ & $53.4 \%$ & $15.8 \%$ & $1.3 \%$ \\
\cline { 2 - 7 } & Rubbish collection & $1.8 \%$ & $13.7 \%$ & $53.4 \%$ & $28.2 \%$ & $1.1 \%$ \\
\hline
\end{tabular}

The above result indicates a higher proportion of satisfied respondents in attributes of Column/beam, Roof, Slabs, Electrical services and Plumbing system. However, 47.4\% respondents (that were 179 out of 380 respondents) are only moderately satisfied with Fire system. It was found that more than $50 \%$ of the respondents were moderately satisfied for the attributes of Playground, Vehicle Parking, Traffic safety, Drainage cleanliness, and Rubbish collection. On the other hand, $80.80 \%$ of the respondents (which is made up of $62.1 \%$ of dissatisfied and $18.7 \%$ of very dissatisfied respondents) had expressed their dissatisfaction with Lift. The respondents claimed that they were dissatisfied with the performance of the lift that was regularly not functioning well and frequently 
break down. For further discussion of the result, the analysis of occupants' satisfaction for each attributes is summarised in a descending order as per Table 3. The degree of satisfaction is calculated using One-Sample Statistic (T-test) by listing the average degree (mean rank) based on the given scale of satisfaction; i.e. 1 to 5 .

Table 3: Mean Rank score for Occupants' satisfaction level

\begin{tabular}{|l|c|c|c|}
\hline \multirow{2}{*}{\multicolumn{1}{c|}{$\begin{array}{c}\text { Attributes of Safety } \\
\text { Performance }\end{array}$}} & \multicolumn{3}{c|}{ Occupants' Satisfaction Survey (Oss) Result } \\
\cline { 2 - 4 } & 1380 & Mean & Standard Deviation \\
\hline Security bar / metal grille & 1354 & 3.63 & 0.6745 \\
\hline Column / beam & 1344 & 3.59 & 0.6706 \\
\hline Door / window & 1336 & 3.56 & 0.7049 \\
\hline Roof & 1286 & 3.55 & 0.6632 \\
\hline Slabs & 1292 & 3.44 & 0.7101 \\
\hline Plumbing System & 1289 & 3.43 & 0.7893 \\
\hline Sanitary fittings & 1255 & 3.39 & 0.7559 \\
\hline Floor finishes & 1250 & 3.30 & 0.6971 \\
\hline Wall finishes & 1235 & 3.30 & 0.7151 \\
\hline Tiling works & 1235 & 3.28 & 0.6861 \\
\hline Indoor temperature & 1240 & 3.28 & 0.7389 \\
\hline Internal ventilation & 1217 & 3.27 & 0.6567 \\
\hline Playground & 1192 & 3.25 & 0.6149 \\
\hline Plastering works & 1188 & 3.21 & 0.7169 \\
\hline Visual obstruction & 1168 & 3.14 & 0.7950 \\
\hline Rubbish collection & 1175 & 3.13 & 0.7269 \\
\hline Painting works & 1151 & 3.12 & 0.6897 \\
\hline Traffic Safety & 1177 & 3.11 & 0.6553 \\
\hline Ceiling finishes & 1170 & 3.11 & 0.8226 \\
\hline Fire System & 1161 & 3.10 & 0.7491 \\
\hline Electrical Services & 1122 & 3.08 & 0.9045 \\
\hline Vehicle Parking & 1074 & 3.01 & 0.6975 \\
\hline Drainage cleanliness & 767 & 2.85 & 0.7895 \\
\hline Lift & & 2.05 & 0.7390 \\
\hline
\end{tabular}

Table 3 shows the summated score, mean score and the standard deviation that represents the distribution of the occupants' satisfaction level around the mean; ranging from scale 1 to 5 (very dissatisfied to very satisfied). The obtained mean rank is range from the highest order of mean=3.63 $(\mathrm{sd}=0.6745)$ to the lowest order, mean $=2.05(\mathrm{sd}=0.7390)$. This result has indicated a smaller dispersion of tabulation that showed a higher degree of consistency on all performance scores. It reveals that the occupants' satisfaction of all attributes is generally reaching an average satisfaction that neither being satisfied nor neither dissatisfied. Even though the valid case is not similar with the result of SPIS (due to several incomplete responses from respondent's form), the attributes were meticulously allied with the safety performance result obtained from the inspection survey. It was found that similar attribute, i.e. Lift, ranked as the lowest satisfaction by the occupants, which associated to the similar attribute ranked as the lowest safety performance in inspection survey. Since majority of the attributes attained mean ranking score ranging from 3.00 to 3.99 (medium satisfaction), therefore, much improvement needs to be strategized to enhance the residents' satisfaction upon their safety needs. 


\subsection{Perception on the Necessity of Housing}

In the next question, the respondents were required to prioritize the aspects by allocating the ranking position for each aspect. The outcome is able to establish the most and the least important aspects needed by the occupants. The result for this question is shown as per Table 4 .

Table 4: Percentage Analysis and Mean Rank score on Occupants' Necessity of Housing

\begin{tabular}{|l|c|c|c|c|c|c|c|}
\hline \multirow{2}{*}{ Aspects } & \multicolumn{2}{|c|}{ Mode of Percentage on the Required Safety Aspects } & \multirow{2}{*}{ Mean } & \multirow{2}{*}{$\begin{array}{c}\text { Standard } \\
\text { Deviation }\end{array}$} \\
\cline { 2 - 6 } & $\begin{array}{c}\text { Very } \\
\text { Disagree }\end{array}$ & Disagree & Medium & Agree & $\begin{array}{c}\text { Very } \\
\text { Agree }\end{array}$ & & \\
\hline $\begin{array}{l}\text { Need for security } \\
\text { (theft/burglary/crime) }\end{array}$ & $2.6 \%$ & $0.5 \%$ & $3.7 \%$ & $10.3 \%$ & $82.6 \%$ & 4.70 & 0.7957 \\
\hline $\begin{array}{l}\text { Need quiet and peaceful } \\
\text { environment }\end{array}$ & $0.5 \%$ & $1.8 \%$ & $5.8 \%$ & $1.6 \%$ & $80.3 \%$ & 4.69 & 0.7099 \\
\hline $\begin{array}{l}\text { Need for building safety } \\
\text { features }\end{array}$ & $0 \%$ & $2.1 \%$ & $6.1 \%$ & $18.7 \%$ & $72.6 \%$ & 4.63 & 0.6956 \\
\hline $\begin{array}{l}\text { Need for regular, scheduled } \\
\text { and routine maintenance }\end{array}$ & $0.5 \%$ & $1.8 \%$ & $9.7 \%$ & $12.9 \%$ & $75 \%$ & 4.60 & 0.7810 \\
\hline $\begin{array}{l}\text { Need for facilitates the } \\
\text { evacuation of occupants in } \\
\text { case of emergency }\end{array}$ & $1.8 \%$ & $1.1 \%$ & $8.2 \%$ & $13.2 \%$ & $75.8 \%$ & 4.60 & 0.8302 \\
\hline $\begin{array}{l}\text { Improve quality of building } \\
\text { structures }\end{array}$ & $0.5 \%$ & $1.8 \%$ & $8.7 \%$ & $24.2 \%$ & $64.2 \%$ & 4.51 & 0.7751 \\
\hline $\begin{array}{l}\text { Need provision of "fit for } \\
\text { purpose" layout }\end{array}$ & $0 \%$ & $2.4 \%$ & $13.4 \%$ & $15.5 \%$ & $68.7 \%$ & 4.51 & 0.8138 \\
\hline $\begin{array}{l}\text { Need for safer } \\
\text { amenities/facilities }\end{array}$ & $0 \%$ & $2.4 \%$ & $10 \%$ & $30.3 \%$ & $56.8 \%$ & 4.42 & 0.7678 \\
\hline $\begin{array}{l}\text { Need for clean and hygienic } \\
\text { environmental conditions }\end{array}$ & $1.8 \%$ & $0.5 \%$ & $16.1 \%$ & $19.5 \%$ & $61.8 \%$ & 4.39 & 0.9033 \\
\hline $\begin{array}{l}\text { Improve quality of } \\
\text { architectural conditions }\end{array}$ & $2.4 \%$ & $1.1 \%$ & $12.1 \%$ & $25.5 \%$ & $58.9 \%$ & 4.38 & 0.9090 \\
\hline $\begin{array}{l}\text { Need isolated from noise and } \\
\text { air pollution sources }\end{array}$ & $0 \%$ & $2.4 \%$ & $13.7 \%$ & $28.9 \%$ & $55 \%$ & 4.37 & 0.8059 \\
\hline $\begin{array}{l}\text { Need for secure play areas for } \\
\text { children }\end{array}$ & $0.5 \%$ & $2.4 \%$ & $10.5 \%$ & $45.8 \%$ & $40.8 \%$ & 4.24 & 0.7743 \\
\hline
\end{tabular}

Based on the result showed in Table 4, majority of the respondents are highly agreed that all of the aspects were vitally needed by them during their tenancy period in the housing. It was found that the items that received more than $70 \%$ responses in the higher scale of agreement are i) safety features, ii) security aspects, iii) healthy environment, iv) cleanliness, and v) peaceful environment. These five (5) aspects are however categorized under different scopes of responsibilities and consideration. The provision of safety aspects should be emphasized in building design factors and quality factors by the relevant building players. As the occupancy stage needs to be prolong and to ensure that the occupants' safety are balanced and secured, the factors must be considered as priority allocation during early development stage of the housing. For the aspects of health environment, cleanliness and peaceful environment, the consideration should be emphasized to the community and society of the housing complex. Security aspects can be categorized for both responsibility of building players and the community. Security measures in avoiding crime cases could be enhanced by apportioning a proper design layout of fencing, parking, internal unit and other potential crime areas. It could be also enhanced by the community initiatives to appoint more security volunteers and encouraged the society to participate in preventing crime cases 


\section{Conclusions}

The research study noted that many ideas and solution are developed to achieve a safe low cost housing delivered to the occupants. The analysis has used strategic approach to achieve the best quality in building services, whereby the assessment integrates the occupants' behavior, perception and opinion as the building user. It is hoped that the outcome of this survey able to provide vital inputs to government agencies such as Kuala Lumpur City Hall (DBKL), Ministry of Housing and Local Government (KPKT) or Fire Rescue Department Malaysia (BOMBA), to propose a modification and improvement on the safety performance and maintenance in low cost housing during occupancy period. Limitations of this research pointed several aspects on safety performance issues, focusing on PPR housing in Kuala Lumpur with participation of responses from the occupants. Future research by any individuals or authoritative bodies on similar topic of this research is highly encouraged.

\section{Acknowledgements}

The authors wish to acknowledge the support of research grant for this research under Exploratory Research Grant Scheme (ERGS) Phase 1/2011 funded by Ministry of Higher Education, Malaysia (KPT) and also to Universiti Teknologi MARA, Perak.

\section{References}

1. A. Ramly, N.A. Ahmad, and N.H. Ishak, "The Effects Of Design On The Maintenance Of Public Housing Buildings In Malaysia - Part One,” Building Engineer (ABE International), no. April, pp. 30-33, 2006.

2. C.C.K.D. Kowaltowski, V.G. Da Silva, S.A.MG. Pina, L.C. Labaki, R.C. Ruschel, and D. de C. Moreira, "Quality of life and sustainability issues as seen by the population of low-income housing in the region of Campinas , Brazil," Habitat Int., vol. 30, pp. 1100-1114, 2006.

3. K. Mearns, S.M. Whitaker, and R. Flin, "Safety climate, safety management practice and safety performance in offshore environments," Saf. Sci., vol. 41, no. 8, pp. 641-680, Oct. 2003.

4. Y. Yau, "The Safety Performance of Apartment Buildings : Empirical Evidence from Hong Kong [PhD Thesis]," The University of Hong Kong, 2006.

5. S.T. Wang, D. C. W. Ho, and W. Chen, "An introduction to the health concern in the Dwelling Performance Rating System in Mainland China, in E.H.W. Chan and D.C.W. Ho (eds.)," in Proceeding of CII-HK Conference 2005 on Healthy Building, Community Health and the Built Environment, 2005, pp. 95-108.

6. A.B. Junaidi, R. Fauzi, and A.S. Ghazali, "Penilaian awal impak perlaksanaan Dasar Perumahan Negara terhadap sektor perumahan di Kuala Lumpur," Geogr. Online Malaysia J. Soc. Sp., vol. 6, no. 6, pp. 90-108, 2012.

7. I. Darkwa, "Post-occupancy evaluation of state-subsidised housing units in Kayamandi, Stellenbosch [PhD Thesis]," University of Stellenbosch, 2006.

8. M. Way and B. Bordass, "Making feedback and post-occupancy evaluation routine 2: Soft landings - involving design and building teams in improving performance," Build. Res. Inf., vol. 33, no. 4, pp. 353-360, Jul. 2005.

9. M.A. Mohit, M. Ibrahim, and Y. R. Rashid, "Assessment of residential satisfaction in newly designed public low-cost housing in Kuala Lumpur, Habitat Int., vol. 34, no. 1, pp. 18-27, 2010.

10. N. Khalil, A.H. Nawawi, H.N. Husin, and H. Adnan, "Correlation of Building Performance and Occupant's Satisfaction via Post Occupancy Evaluation for Malaysia's Public Buildings," in Proceedings of 5th International Conference on Construction in the 21st Century (CITC-V) "Collaboration and Integration in Engineering, Management and Technology, 2009, pp. 1035 1042. 